\title{
Growth and Gas Exchange of Cucurbita pepo L. Under Nitrogen and Silicon Fertilization
}

\author{
Jackson de M. Alves ${ }^{1}$, Alex S. de Lima ${ }^{1}$, Cesenildo de F. Suassuna ${ }^{2}$, Francisco R. A. Figueiredo ${ }^{3}$, \\ Toshik Iarley da Silva ${ }^{4}$, Evandro F. de Mesquita ${ }^{5}$, Lourival F. Cavalcante ${ }^{6} \&$ Francisco de O. Mesquita $^{7}$ \\ ${ }^{1}$ Department of Exact and Agrarian Science, State University of Paraiba, Catolé do Rocha, PB, Brazil \\ ${ }^{2}$ Postgraduate Program in Tropical Horticulture, Federal University of Campina Grande, Pombal, PB, Brazil \\ ${ }^{3}$ Postgraduate Program in Plant Science, Federal Rural University of the Semi-Arid, Mossoró, RN, Brazil \\ ${ }^{4}$ Department of Plant Science, Federal University of Viçosa, Viçosa, MG, Brazil \\ ${ }^{5}$ Department of Agronomy, Federal University of Campina Grande, Pombal, PB, Brazil \\ ${ }^{6}$ Department of Soil and Rural Engineering, Federal University of Paraiba, Areia, PB, Brazil \\ ${ }^{7}$ Department of Agronomy, Federal University of Cariri, Crato, CE, Brazil \\ Correspondence: Toshik Iarley da Silva, Federal University of Viçosa, Department of Plant Science, Viçosa, \\ Minas Gerais, Brazil. E-mail: toshik.silva@ufv.br
}

Received: March 17, 2019

Accepted: April 22, $2019 \quad$ Online Published: June 30, 2019

doi:10.5539/jas.v11n9p83

URL: https://doi.org/10.5539/jas.v11n9p83

\begin{abstract}
Zucchini (Cucurbita pepo L.) is a horticultural crop of great socioeconomic importance in Brazil and in the world. However, inappropriate fertilization management, such as over-fertilization of soils, may become a limiting factor for its development. Thus, the aim of this study was to evaluate the morpho-physiological behavior of zucchini submitted to nitrogen $(\mathrm{N})$ doses applied via soil and foliar application of silicon $(\mathrm{Si})$. The treatments were distributed in split-plot scheme in a randomized block design, with three replications. The plot was formed by silicon levels $\left(0.0\right.$ and $\left.6.0 \mathrm{~g} \mathrm{plant}^{-1}\right)$ and the subplots constituted by five nitrogen levels $(30,60$, 90,120 and $150 \mathrm{~kg} \mathrm{ha}^{-1}$ ), adding up to 30 experimental units. Gas exchanges and growth parameters were assessed at 35 days after planting. The data were submitted to analysis of variance by the $\mathrm{F}$ test and in the cases of significance was performed a polynomial regression analysis for the nitrogen factor and Tukey test for the silicon factor. The supply of Si positively enhances the effects of $\mathrm{N}$ on growth characteristics and gas exchanges of zucchini. The simultaneous application of $\mathrm{Si}$ and $\mathrm{N}$ does not influence the leaf area of zucchini. The $\mathrm{N}$ dose of $93.9 \mathrm{~kg} \mathrm{ha}^{-1}$ provides greater assimilation of $\mathrm{CO}_{2}$ in zucchini plants under the conditions in which the experiment was performed.
\end{abstract}

Keywords: Zucchini, fertilizers, morpho-physiological traits

\section{Introduction}

The zucchini or courgette (Cucurbita pepo L.) is a summer squash that belongs to the family Cucurbitaceae. The center of origin of zucchini is the tropical Americas, specifically Central Mexico and South of the United States of America. In Brazil, the average yield of this vegetable varies from 8 to $10 \mathrm{tha}^{-1}$ (Filgueira, 2012). According to Carpes et al. (2008), the zucchini is among the ten vegetables of greatest economic value in Brazil.

Inadequate fertilization management is one of the main factors impairing the growth, development and productivity of zucchini. Nitrogen is the key limiting nutrient for most crops. Therefore, nitrogen fertilization is of fundamental importance, since nitrogen $(\mathrm{N})$ is an essential macro-nutrient that directly influences plant growth and development, affecting the source-sink relationship and photoassimilate distribution between the vegetative and reproductive organs (Porto et al., 2012). In this context, scarce nitrogen content in the soil causes nitrogen deficiency in plants, negatively affecting its biochemical and physiological processes and, consequently, the growth (Pedo et al., 2014). On the other hand, beneficial effects of nitrogen fertilization are reported by several authors in different crops, such as Antunes et al. (2014) in African cucumber (Cucumis metuliferus L.), Porto et al. (2012) in zucchini (Cucurbita pepo L.) and Morais et al. (2015) in maize plants (Zea mays L.). 
The rational use of nitrogen fertilizers is important, since excessive $\mathrm{N}$ content in the soil can be harmful to both the plant and the environment. In this sense, better yields can be achieved by the combination of nitrogen and silicon (Si) fertilization (Artigiani et al., 2014). Although not an essential nutrient, silicon is beneficial to plants, being associated with several indirect effects on plants, especially enhanced photosynthetic capacity, reduced transpiration and increased mechanical resistance of the cells (Ferraz et al., 2014).

Thus, the rational application of these fertilizers, in order to improve the nitrogen use efficiency in plants, is of fundamental importance for the development of sustainable agriculture (Xu, Fan, \& Miller, 2012). Given the scarcity of information on the joint action of these nutrients, especially in vegetables, the aim of this work was to evaluate the morphophysiological behavior of zucchini submitted to nitrogen doses applied via soil and foliar application of silicon.

\section{Material and Methods}

The experiment was carried out under field conditions in the Agroecology Sector of the Agrarian and Exact Sciences Department (DAE) of the State University of Paraíba (UEPB), Campus IV, located in the municipality of Catolé do Rocha, Paraíba, Brazil, having the geographical coordinates of $6^{\circ} 20^{\prime} 38^{\prime \prime} \mathrm{S}$ and $37^{\circ} 44^{\prime} 48^{\prime \prime} \mathrm{W}$, with an altitude above sea level of $275 \mathrm{~m}$.

The zucchini cultivar 'Caserta' was used in the experiment, being conducted in a spacing of $1 \times 1 \mathrm{~m}$. Planting was done by direct sowing in pits. Pits of $30 \times 30 \times 30 \mathrm{~cm}$ size were dug, then $2 \mathrm{~L}$ of cattle manure were added in each.

The soil of the experimental area is classified as eutrophic Fluvic Neosoil, with a sandy loam texture (Embrapa, 2011). Before the experiment started, soil samples were collected in the $0-20 \mathrm{~cm}$ depth for physical and fertility analysis (Table 1) and the chemical analysis of the cattle manure was performed (Table 2), according to the methodology proposed by Embrapa (2011). The soil was prepared by plowing sequenced by harrowing.

Table 1. Chemical and physical characteristics of the eutrophic fluvic neosoil used in the experiment

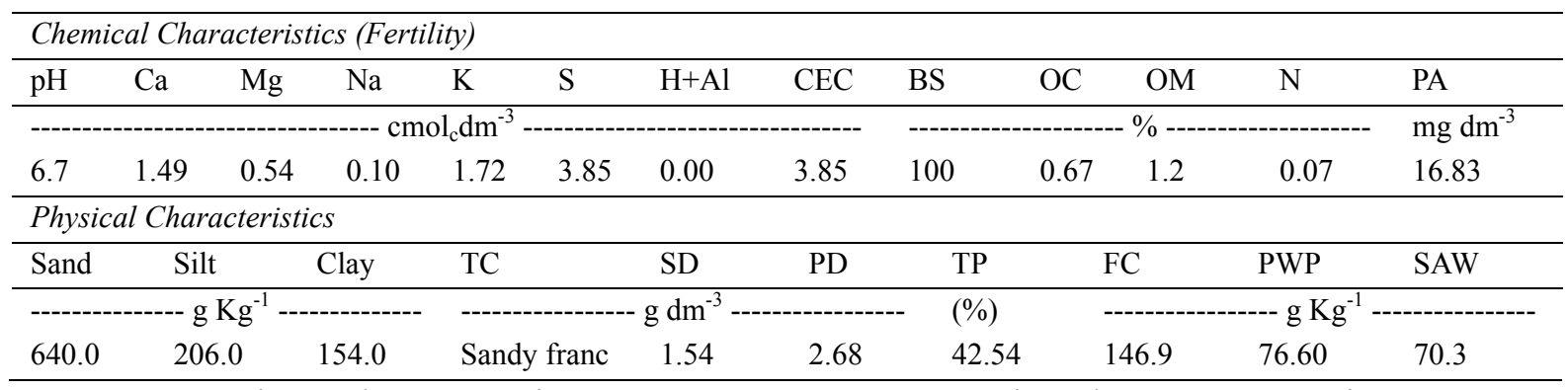

Note. CEC $=$ Cation exchange capacity; $\mathrm{BS}=$ Base sum; $\mathrm{OC}=$ organic carbon; $\mathrm{OM}=$ organic matter; $\mathrm{PA}=$ Phosphor assimilable; $\mathrm{TC}=$ textural class; $\mathrm{SD}=$ soil density; $\mathrm{PD}=$ particle density; $\mathrm{TP}=$ total porosity $; \mathrm{FC}=$ field capacity; $\mathrm{PWP}=$ permanent wilting point; $\mathrm{SAW}=$ soil available water.

The treatments were distributed in split-plot scheme in a randomized block design (RBC), with three replications. The plot was formed by silicon levels $\left(0.0\right.$ and $\left.6.0 \mathrm{~g} \mathrm{plant}^{-1}\right)$ and the subplots constituted by five nitrogen levels $\left(30 ; 60 ; 90 ; 120\right.$ and $\left.150 \mathrm{~kg} \mathrm{ha}^{-1}\right)$. The nitrogen source used was urea $(45 \% \mathrm{~N})$. The silicon levels were based on an estimate of $60 \mathrm{~kg} \mathrm{ha}^{-1}$. The silicon source used was Bugram Protect ${ }^{\circledR}$, with 100\% pure silicon dioxide, $\mathrm{pH} 6 / 8$ and $0.90 \%$ moisture. The $\mathrm{N}$ doses were equally divided and applied to the soil twice, first at $15 \mathrm{DAP}$ (days after planting) and the second application at 30 DAP. Si was also divided into two applications, the first at 14 DAP and the second at $28 \mathrm{DAP}$, both via foliar. Thus, in the first application $540 \mathrm{~g}$ of silicon dioxide was diluted in 30 $\mathrm{L}$ of water. In the second application $540 \mathrm{~g}$ was diluted in $40 \mathrm{~L}$ of water. The silicon solutions were uniformly applied using a $10 \mathrm{~L}$ capacity backpack sprayer. In total, $1.080 \mathrm{~kg}$ of silicon dioxide were used in the present study.

Micro-irrigation was performed through a drip irrigation system, spaced at $0.2 \mathrm{~m}$ and with a flow rate of 1.7 liters per hour, at a service pressure of $147 \mathrm{kPa}$, using $16 \mathrm{~mm}$ drip tapes. The water was supplied through an Amazon well near the experiment site, and it is classified as moderately saline $\left(1.2 \mathrm{dS} \mathrm{m}^{-1}\right)$ (Ayers \& Westcot, 1999). 
The physiological analyzes were performed at $35 \mathrm{DAP}$, between 9:00 and 10:00 am, using the portable infrared gas analyzer (IRGA-model LI-6400XT, LI-COR ${ }^{\circledR}$, Nebraska, USA) with $300 \mathrm{~mL} \mathrm{~min}^{-1}$ air flow and coupled light source of $1200 \mu \mathrm{mol} \mathrm{m} \mathrm{m}^{-2}$ The following variables were assesed: net $\mathrm{CO}_{2}$ assimilation rate $\left(\mathrm{A}-\mu \mathrm{mol} \mathrm{CO}_{2}\right.$ $\mathrm{m}^{-2} \mathrm{~s}^{-1}$ ), stomatal conductance (gs-mol m $\left.\mathrm{m}^{-2} \mathrm{H}_{2} \mathrm{O} \mathrm{s}{ }^{-1}\right), \mathrm{CO}_{2}$ concentration in intercellular spaces $\left(\mathrm{Ci}-\mu \mathrm{mol} \mathrm{CO} \mathrm{Cm}^{-2}\right.$ $\left.\mathrm{s}^{-1}\right)$, transpiration rate $\left(\mathrm{E}-\mathrm{mmol} \mathrm{H}_{2} \mathrm{O} \mathrm{m}^{-2} \mathrm{~s}^{-1}\right)$ and leaf temperature $\left(\mathrm{TF}-{ }^{\circ} \mathrm{C}\right)$ and from these, the water use efficiency (WUE-A/E) and instantaneous carboxylation efficiency (iCE-A/Ci) were calculated. For the growth parameters, the following variables were measured: plant height, stem diameter, leaf number and leaf area.

The data were submitted to analysis of variance by the $\mathrm{F}$ test at $5 \%$ probability. Polynomial regression analysis for the nitrogen factor and Tukey test for the silicon factor were performed in case of significance. The statistical program R was used (R Core Team, 2018).

\section{Results and Discussion}

There was interaction between the studied factors, except for the leaf area. Plant height, stem diameter, leaf number and leaf area were influenced by the interaction between nitrogen $(\mathrm{N})$ and silicon $(\mathrm{Si})$, being the highest values for these variables obtained with the application of Si (Table 2).

Table 2. Average values for plant height, stem diameter, leaf number and leaf area of zucchini (Cucurbita pepo L.) under nitrogen doses and silicon leaf fertilization

\begin{tabular}{|c|c|c|c|c|c|c|}
\hline \multirow{2}{*}{ Parameters } & \multirow{2}{*}{$\begin{array}{l}\text { Silicon } \\
\left(\text { g planta }^{-1}\right)\end{array}$} & \multicolumn{5}{|c|}{ Nitrogen $\left(\mathrm{kg} \mathrm{ha}^{-1}\right)$} \\
\hline & & 30 & 60 & 90 & 120 & 150 \\
\hline \multirow{2}{*}{ Plant lenght } & 0 & $14.23 \mathrm{~b}$ & $17.99 \mathrm{a}$ & $21.15 \mathrm{a}$ & $16.57 \mathrm{~b}$ & $19.24 \mathrm{~b}$ \\
\hline & 6 & $15.87 \mathrm{a}$ & $19.00 \mathrm{a}$ & $17.29 \mathrm{~b}$ & $18.51 \mathrm{a}$ & $21.37 \mathrm{a}$ \\
\hline \multirow{2}{*}{ Stem diameter } & 0 & $18.32 \mathrm{~b}$ & $19.02 \mathrm{a}$ & $19.64 \mathrm{a}$ & $19.95 \mathrm{a}$ & $21.15 \mathrm{a}$ \\
\hline & 6 & $19.11 \mathrm{a}$ & $16.14 \mathrm{~b}$ & $17.17 \mathrm{~b}$ & $17.26 \mathrm{~b}$ & $20.24 \mathrm{~b}$ \\
\hline \multirow{2}{*}{ Number of leaves } & 0 & $14.00 \mathrm{a}$ & $14.67 \mathrm{~b}$ & $18.00 \mathrm{~b}$ & $14.67 \mathrm{~b}$ & $11.67 \mathrm{~b}$ \\
\hline & 6 & $14.67 \mathrm{a}$ & $16.67 \mathrm{a}$ & $20.33 \mathrm{a}$ & $16.67 \mathrm{a}$ & $15.00 \mathrm{a}$ \\
\hline \multirow{2}{*}{ Leaf area } & 0 & $6480.55 \mathrm{a}$ & $7387.90 \mathrm{a}$ & $7454.20 \mathrm{a}$ & $6419.40 \mathrm{a}$ & $7035.92 \mathrm{a}$ \\
\hline & 6 & $5768.75 \mathrm{~b}$ & $6157.45 \mathrm{~b}$ & $5173.02 \mathrm{~b}$ & $5461.33 \mathrm{~b}$ & $5598.22 \mathrm{~b}$ \\
\hline
\end{tabular}

For the plant height, in the treatment without application of $\mathrm{Si}$, the values adjusted to a quadratic effect, with the greatest increase obtained at $99.4 \mathrm{~kg} \mathrm{ha}^{-1}$ of $\mathrm{N}$. On the other hand, under the application of $\mathrm{Si}$, a linear increase in plant height is observed as the $\mathrm{N}$ doses increases. There was a $28.9 \%$ increase in plant height at the nitrogen dose of $150 \mathrm{~kg} \mathrm{ha}^{-1}$ when compared to the control treatment $\left(30 \mathrm{~kg} \mathrm{ha}^{-1}\right)$ (Figure 1A). For the leaf number, the application of silicon provided better results, with greater efficiency being found at the $\mathrm{N}$ dose of $88.2 \mathrm{~kg} \mathrm{ha}^{-1}$ (Figure 1B). The beneficial effect of silicon can be associated with several indirect factors that stimulate growth and plant production. Silicon in plants promotes strengthening of the cell walls, increasing the amount of water in the plant and, consequently, of photoassimilates (Adrees et al., 2015).
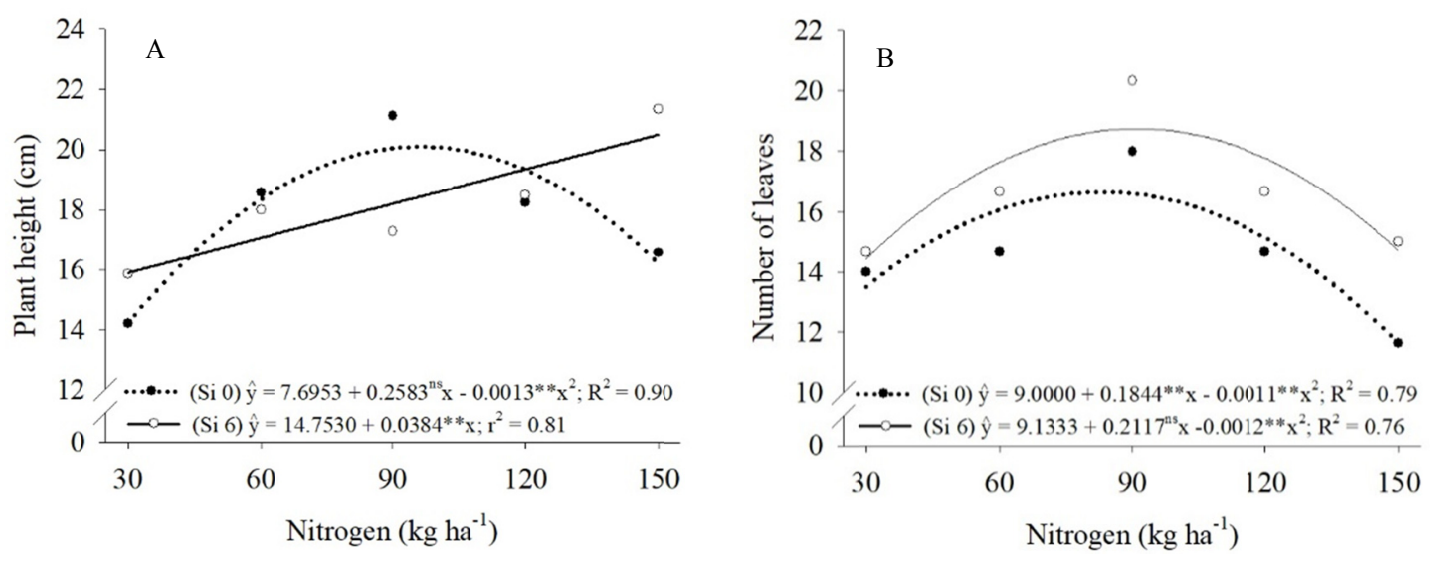

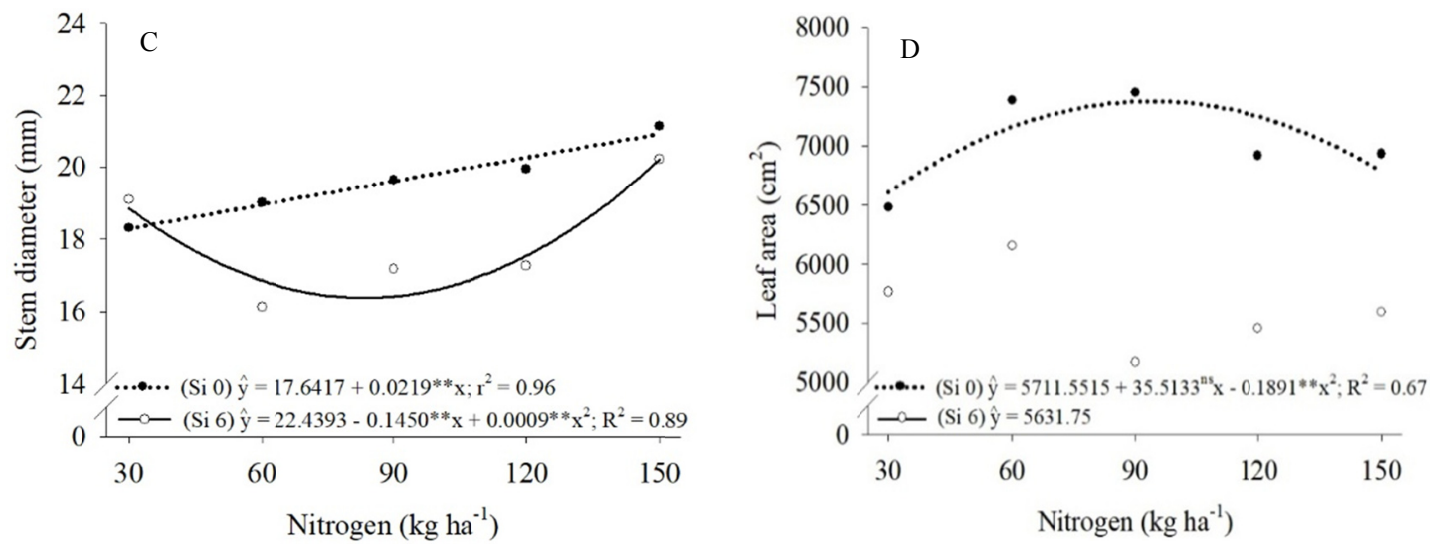

Figure 1. Plant height (A), leaf number (B), stem diameter (C), and leaf area (D) in zucchini (Cucurbita pepo L.) under nitrogen doses and silicon leaf fertilization

For the stem diameter and leaf area, the best results were obtained in the treatments without silicon application, with higher increases at the $\mathrm{N}$ doses of 150 and $93.9 \mathrm{~kg} \mathrm{ha}^{-1}$, respectively (Figures 1C and 1D). This behavior can be attributed to the fact that nitrogen is part of the photosynthetic apparatus, e.g., being constituent of chlorophyll molecules, providing increased photosynthetically active leaf area, leading to greater $\mathrm{CO}_{2}$ assimilation, thus resulting in improved growth and development (Basra, Iqbal, \& Afbal, 2014).

Positive results from the use of nitrogen fertilizers were found by Liu et al. (2015) in lettuce plants (Lactuca sativa L.). Beneficial effects of silicon are reported by Keller et al. (2015) in hydroponically grown wheat seedlings (Triticum turgidum L.) under different doses of copper.

Stomatal conductance, net $\mathrm{CO}_{2}$ assimilation, transpiration rate, internal $\mathrm{CO}_{2}$ concentration, water use efficiency, instantaneous carboxylation efficiency and leaf temperature were altered by the interaction between nitrogen $(\mathrm{N})$ and silicon $(\mathrm{Si})$, with the highest values for these variables obtained with the application of $\mathrm{Si}$ (Table 3 ).

Table 3. Mean values for stomatal conductance (gs), net $\mathrm{CO}_{2}$ assimilation rate (A), transpiration rate (E), $\mathrm{CO}_{2}$ concentration in intercellular spaces (Ci), water use efficiency (WUE), instantaneous carboxylation efficiency (iCE) and leaf temperature $\left(\mathrm{T}_{\text {Leaf }}\right)$ of zucchini (Cucurbita pepo $\mathrm{L}$.) under nitrogen doses and silicon leaf fertilization

\begin{tabular}{|c|c|c|c|c|c|c|}
\hline \multirow{2}{*}{ Parameters } & \multirow{2}{*}{$\begin{array}{l}\text { Silicon } \\
\left(\text { g planta }^{-1}\right)\end{array}$} & \multicolumn{5}{|c|}{ Nitrogen $\left(\mathrm{kg} \mathrm{ha}^{-1}\right)$} \\
\hline & & 30 & 60 & 90 & 120 & 150 \\
\hline \multirow{2}{*}{ gs } & 0 & $0.239 \mathrm{~b}$ & $0.263 \mathrm{~b}$ & $0.324 \mathrm{~b}$ & $0.213 \mathrm{~b}$ & $0.204 \mathrm{~b}$ \\
\hline & 6 & $0.278 \mathrm{a}$ & $0.308 \mathrm{a}$ & $0.370 \mathrm{a}$ & $0.245 \mathrm{a}$ & $0.237 \mathrm{a}$ \\
\hline \multirow{2}{*}{$\mathrm{A}$} & 0 & $9.384 \mathrm{~b}$ & $11.623 \mathrm{~b}$ & $17.598 \mathrm{~b}$ & $14.200 \mathrm{~b}$ & $8.577 \mathrm{~b}$ \\
\hline & 6 & $10.691 \mathrm{a}$ & $12.736 \mathrm{a}$ & $19.374 \mathrm{a}$ & $16.776 \mathrm{a}$ & $10.778 \mathrm{a}$ \\
\hline \multirow{2}{*}{$\mathrm{E}$} & 0 & $4.846 \mathrm{~b}$ & $5.494 \mathrm{~b}$ & $8.586 \mathrm{~b}$ & $6.624 \mathrm{a}$ & $4.692 \mathrm{~b}$ \\
\hline & 6 & $6.588 \mathrm{a}$ & $7.295 \mathrm{a}$ & $9.712 \mathrm{a}$ & $6.053 \mathrm{~b}$ & $5.652 \mathrm{a}$ \\
\hline \multirow{2}{*}{$\mathrm{Ci}$} & 0 & $243.167 \mathrm{~b}$ & $259.417 \mathrm{~b}$ & $285.000 \mathrm{a}$ & $238.167 \mathrm{~b}$ & $224.333 \mathrm{~b}$ \\
\hline & 6 & $268.750 \mathrm{a}$ & $276.750 \mathrm{a}$ & $288.733 \mathrm{a}$ & $243.917 \mathrm{a}$ & $229.250 \mathrm{a}$ \\
\hline \multirow{2}{*}{ WUE } & 0 & $1.910 \mathrm{a}$ & $2.065 \mathrm{a}$ & $2.074 \mathrm{a}$ & $2.129 \mathrm{~b}$ & $1.744 \mathrm{~b}$ \\
\hline & 6 & $1.624 \mathrm{~b}$ & $1.736 \mathrm{~b}$ & $1.995 \mathrm{~b}$ & $2.687 \mathrm{a}$ & $1.874 \mathrm{a}$ \\
\hline \multirow{2}{*}{$\mathrm{iCE}$} & 0 & $0.039 \mathrm{a}$ & $0.045 \mathrm{a}$ & $0.062 \mathrm{~b}$ & $0.060 \mathrm{~b}$ & $0.038 \mathrm{~b}$ \\
\hline & 6 & $0.040 \mathrm{a}$ & $0.046 \mathrm{a}$ & $0.067 \mathrm{a}$ & $0.069 \mathrm{a}$ & $0.047 \mathrm{a}$ \\
\hline \multirow{2}{*}{ Tleaf } & 0 & $40.533 \mathrm{a}$ & $35.933 \mathrm{~b}$ & $41.808 \mathrm{~b}$ & $38.257 \mathrm{a}$ & $37.433 \mathrm{a}$ \\
\hline & 6 & $39.783 \mathrm{a}$ & $41.313 \mathrm{a}$ & $43.268 \mathrm{a}$ & $39.200 \mathrm{a}$ & $37.531 \mathrm{a}$ \\
\hline
\end{tabular}

For A, it can be observed that the highest rate $\left(17.80 \mu \mathrm{mol}\right.$ of $\left.\mathrm{CO}_{2} \mathrm{~m}^{-2} \mathrm{~s}^{-1}\right)$ was registered at the $\mathrm{N}$ dose of $93.9 \mathrm{~kg}$ $\mathrm{ha}^{-1}$, showing an $11.5 \%$ increase when compared to the treatment without application of $\mathrm{Si}$, which presented a 
rate of $15.76 \mu \mathrm{mol}$ of $\mathrm{CO}_{2} \mathrm{~m}^{-2} \mathrm{~s}^{-1}$ (Figure 2A). This result may be related to the fact that silicon promotes changes in the plant structure, improving the opening angle of the leaves, which favors a better use of light and consequently boosts photosynthetic efficiency. Also, the results found can be related to a higher nitrate uptake, since the process requires two moles of ATP for each mol of absorbed nitrate (Ávila et al., 2010; Ribeiro et al., 2011).
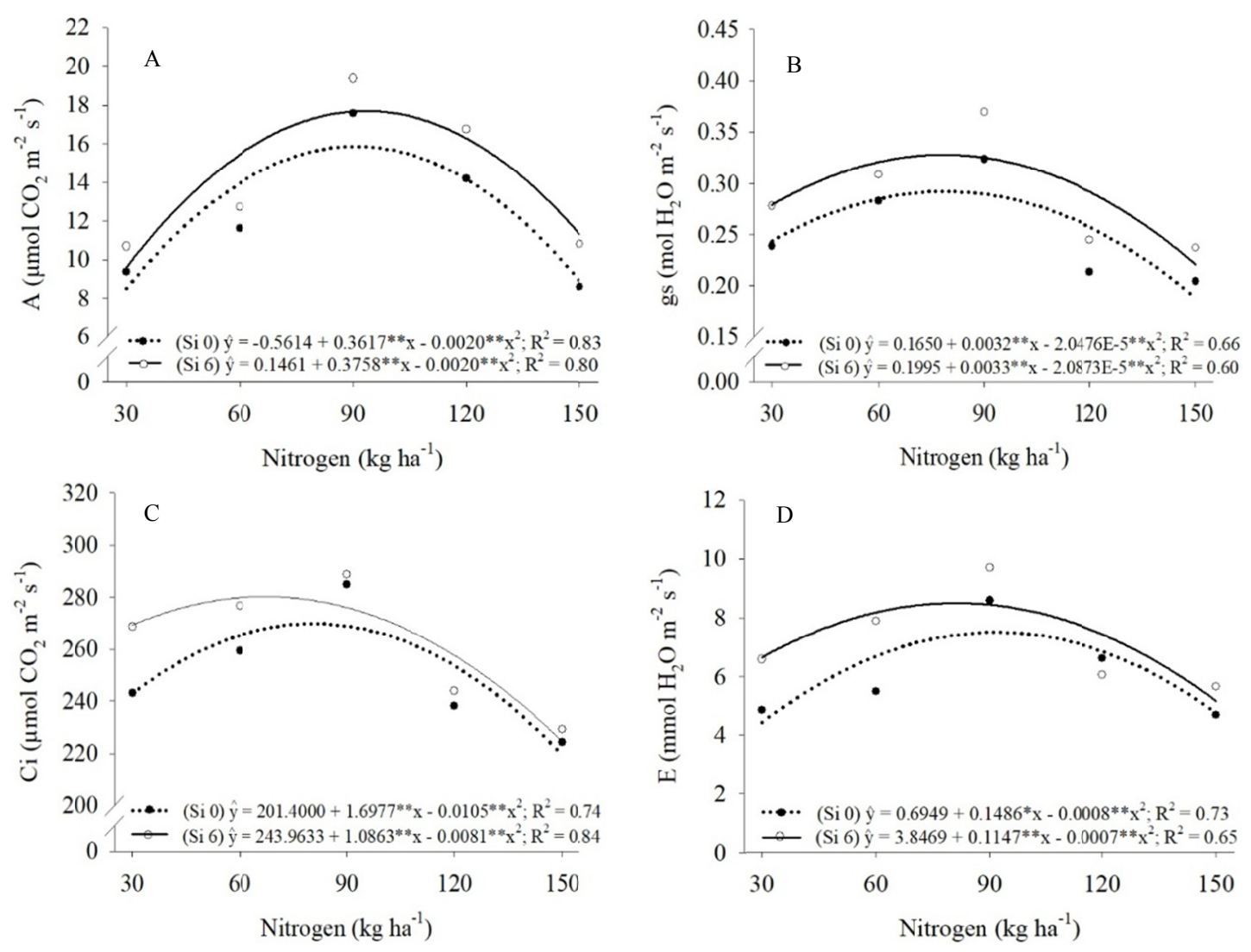

Figure 2. Net $\mathrm{CO}_{2}$ assimilation rate (A-A), stomatal conductance (gs-B), $\mathrm{CO}_{2}$ concentration in intercellular spaces $(\mathrm{Ci}-\mathrm{C})$ and transpiration rate (E-D) of zucchini (Cucurbita pepo L.) under nitrogen doses and silicon leaf fertilization

The variables gs and $\mathrm{Ci}$ presented a similar behavior to $\mathrm{A}$, adjusting to a quadratic effect. The best increments for gs $\left(0.33 \mathrm{~mol}\right.$ of $\left.\mathrm{H}_{2} \mathrm{O} \mathrm{m}^{-2} \mathrm{~s}^{-1}\right)$ and $\mathrm{Ci}\left(280.38 \mu \mathrm{mol}\right.$ of $\left.\mathrm{CO}_{2} \mathrm{~m}^{-2} \mathrm{~s}^{-1}\right)$ were observed at the $\mathrm{N}$ doses of 79.1 and 67.1 $\mathrm{kg} \mathrm{ha}^{-1}$ (Figure 2B and 2C), respectively, under silicon foliar fertilization. This performance may be due to the increases recorded in $\mathrm{A}$, since increased carbon assimilation may induce a greater stomatal opening, thus favoring the entry of $\mathrm{CO}_{2}$ into the cells. The increase of the photosynthesis rate in the mesophyll cells causes the reduction of internal $\mathrm{CO}_{2}$ concentration, which leads to the opening of the stomata (Taiz, Zeiger, Moller, \& Murphy, 2017).

Regarding E, the highest rate $\left(8.55 \mathrm{mmol}\right.$ of $\left.\mathrm{H}_{2} \mathrm{O} \mathrm{m}^{-2} \mathrm{~s}^{-1}\right)$ was registered at the $\mathrm{N}$ dose of $81.9 \mathrm{~kg} \mathrm{ha}^{-1}$, showing a $14.2 \%$ increase when compared to the treatment without application of $\mathrm{Si}\left(7.49 \mathrm{mmol}\right.$ of $\mathrm{H}_{2} \mathrm{O} \mathrm{m}^{-2} \mathrm{~s}^{-1}$ ) (Figure 2D). The increase observed in the transpiration rate may be related to stomatal conductance, since the opening and closing of the stomata regulates the gas exchange between the internal and external media of the leaves.

Increases in stomatal conductance, net $\mathrm{CO}_{2}$ assimilation and transpiration rate were also found by Curvêlo et al. (2013) and Ramos et al. (2013) in cotton (Gossypium hirsutum L.) and zucchini (Cucurbita pepo L.) under silicon foliar application.

Regarding iCE, the best result (0.07) was obtained at the $\mathrm{N}$ dose of $100.4 \mathrm{~kg} \mathrm{ha}^{-1}$, an increase of $40 \%$ compared to the treatment without silicon (0.05) (Figure 3A). This result can be explained by the increase in $\mathrm{CO}_{2}$ assimilation, where a larger amount of carbon is being fixed by Rubisco (Ferraz et al., 2012). 

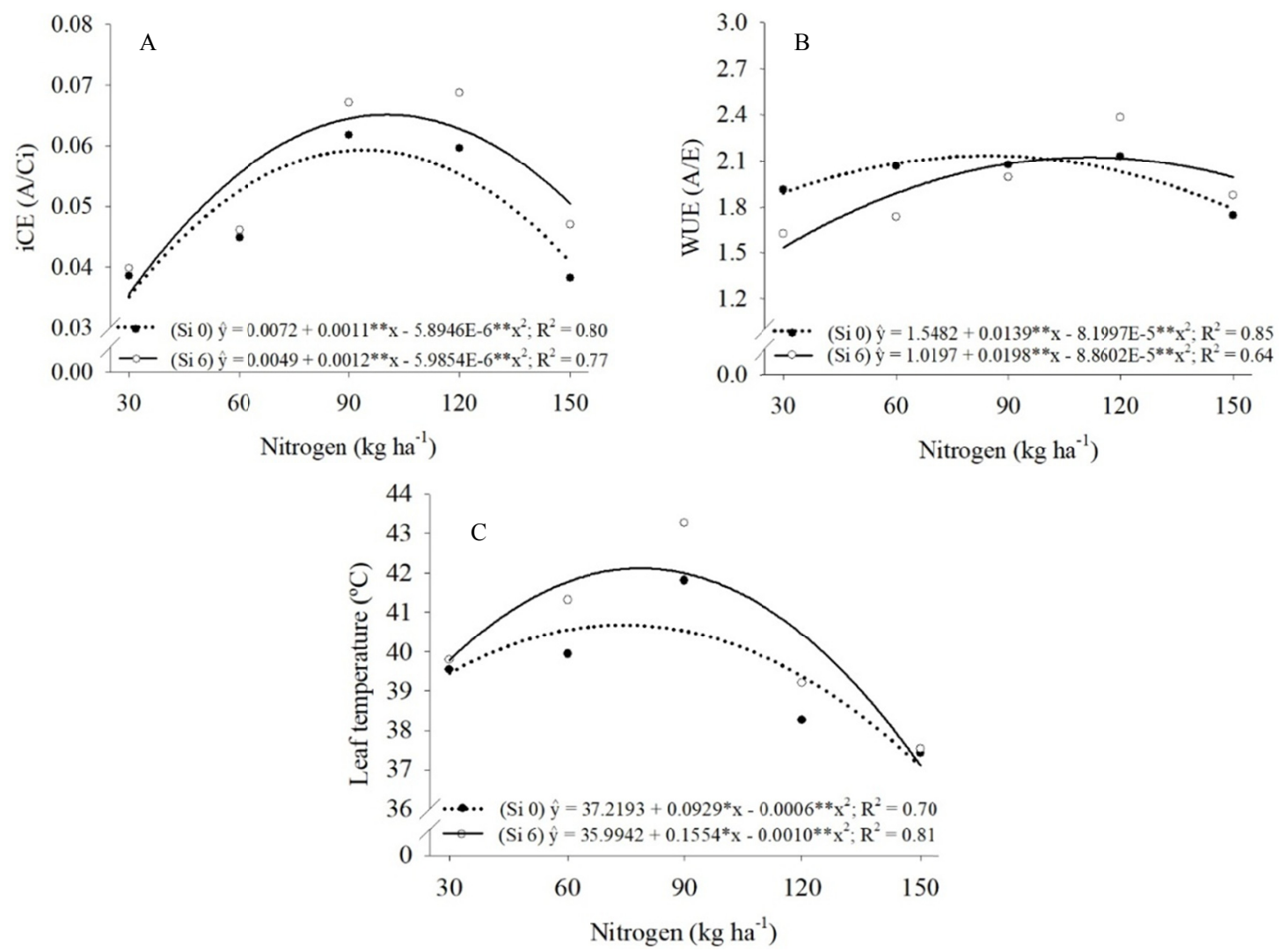

Figure 3. Instantaneous carboxylation efficiency (iCE-A), water use efficiency (WUE-B) and leaf temperature (Tleaf-C) of zucchini (Cucurbita pepo L.) under nitrogen doses and silicon leaf fertilization

The WUE adjusted to a quadratic effect, with the highest efficiency (2.13) obtained at the $\mathrm{N}$ dose of $111.7 \mathrm{~kg} \mathrm{ha}^{-1}$, in the treatment under silicon application (Figure 3B). This result is important, since the WUE is the ratio of the amount of $\mathrm{CO}_{2}$ that the plant assimilates (A) to molecule of water lost through the transpiration process (E) (Lima, Silva, Santos, \& Souza, 2018). Similar results were obtained by Zamboni et al. (2016) in grapevine (Vitis vinifera $\mathrm{L}$.) submitted to nitrogen fertilization.

The interaction between silicon and nitrogen provided a higher leaf temperature $\left(42.03{ }^{\circ} \mathrm{C}\right.$ ), with the highest increase registered at the $\mathrm{N}$ dose of $77.7 \mathrm{~kg} \mathrm{ha}^{-1}$, representing a $3 \%$ increase in relation to the treatment without silicon $\left(40.8{ }^{\circ} \mathrm{C}\right.$ ) (Figure $3 \mathrm{C}$ ). The leaf temperature is related to the transpiration process. The process of transpiration provides the plant with evaporative cooling, when releasing the water vapor through the stomata and cuticles. Through the process of transpiration, the thermal energy is balanced by the loss of heat. Since most of the water within the plant is released through the stomata, leaf temperature is influenced by stomatal conductance, once reduced stomata opening may lead to raise in leaf temperature. Under high temperatures on the leaf surface, plants may suffer some damage in biochemical and physiological processes.

\section{Conclusions}

The supply of Si positively enhances the effects of $\mathrm{N}$ on growth characteristics and gas exchanges of zucchini.

The simultaneous application of Si and $\mathrm{N}$ does not influence the leaf area of zucchini.

The interaction between Si and N positively influences the gas exchanges of zucchini

\section{References}

Adress, M., Ali, S., Rizwan, M., Zia-Ur-Rehman, M., Ibrahim, M., Abbas, F., ... Irshad, M. K. (2015). Mechanisms of silicone-mediated alleviation of heavy metal toxicity in plants: A review. Ecotoxicology and Environmental Satefy, 119(1), 186-197. https://doi.org/10.1016/j.ecoenv.2015.05.011

Antunes, G., Ferreira, A. P. S., Puiatti, M., Cecon, P. R., \& Silva, G. C. C. (2014). Yield and quality of horned cucumber in response to nitrogen fertilization. Revista Ceres, 61(1), 141-146. https://doi.org/10.1590/ S0034-737X2014000100019 
Artigiani, A. C. C. A., Crusciol, C. A. C., Nascente, A. S., Arf, O., \& Alvarez, R. C. F. (2014). Silicon in row and nitrogen in topdressing fertilization on rice under dry land and sprinkler irrigation conditions. Bioscience Journal, 30(1), 240-251.

Ávila, F. W., Baliza, D. P., Faquin, V., Araújo, J. L., \& Ramos, S. J. (2010). Silicon-nitrogen interaction in rice cultivated under nutrient solution. Revista Ciência Agronômica, 41(2), 184-190. https://doi.org/10.1590/ S1806-66902010000200003

Ayers, R. S., \& Westcot, D.W. A. (1999). A qualidade da água na agricultura (2nd ed., p. 153). Campina Grande: UFPB.

Basra, S. M. A., Iqbal, S., \& Afzal, I. (2014). Evaluating the response of nitrogen application on growth, development and yield of quinoa genotypes. International Journal of Agriculture \& Biology, 16(5), 886-892.

Carpes, R. H., Lúcio, A. D., Storck, L., Lopes, S. J., Zanardo, B., \& Paludo, A. L. (2008). Effect of lack of harvested fruits on the variability of fruit biomass of zucchini cultivated in different irrigation systems. Revista Ceres, 55(6), 590-595.

Curvêlo, C. R. S., Rodrigues, F. A., Pereira, L. F., Silva, L. C., Damatta, F. M., \& Berger, P. G. (2013). Leaf gas exchange and oxidative stress on cotton plants supplied with silicon and infected by Ramularia areola. Bragantia, 72(4), 346-359. https://doi.org/10.1590/brag.2013.053

Embrapa (Empresa Brasileira de Pesquisa Agropecuária). (2011). Centro Nacional de Pesquisa de Solos. Manual de métodos e análise do solo (3rd ed., p. 230). Rio de Janeiro, RJ.

Ferraz, R. L. S., Melo, A. S., Suassuna, J. F., Brito, M. E. B., Fernandes, P. D., \& Nunes Júnior, E. S. (2012). Gas exchange and photosynthetic efficiency in common bean ecotypes grown in a semiarid environment. Pesquisa Agropecuária Tropical, 42(2), 181-188. https://doi.org/10.1590/S1983-40632012000200010

Ferraz, R. N. S., Beltrão, N. E. M., Melo, A. S., Magalhães, I. D., Fernandes, P. D., \& Rocha, M. S. (2014). Gas exchange and photochemical efficiency of cotton cultivars under leaf application of silicon. Semina: Ciências Agrárias, 35(2), 735-748. https://doi.org/10.5433/1679-0359.2014v35n2p735

Filgueira, F. A. R. (2012). Novo Manual de Olericultura: Agrotecnologia moderna na produção e comercialização de hortaliças (3rd ed., p. 421). Viçosa: UFV.

Keller, C., Rizwan, M., Davidiano, J. C., Pokrovsky, O. S., Bovet, N., Chaurand, P., \& Meunier, J. D. (2015). Effect of silicone on wheat seedlings (Triticum turgidum L.) grown in hydroponics and exposed to 0 to $30 \mu \mathrm{M}$ Cu. Planta, 241(4), 847-860. http://doi.org/10.1007/s00425-014-2220-1

Lima, B. L. C., Silva, E. F. F., Santos, H. R. B., \& Souza, E. R. (2018). Potassium fertilization and irrigations with treated wastewater on gas exchange of colored cotton. Revista Brasileira de Engenharia Agrícola e Ambiental, 22(11), 741-746. https://doi.org/10.1590/1807-1929/agriambi.v22n11p741-746

Liu, C. W., Sung, Y., Chen, B. C., \& Lai, H. Y. (2014). Effects of nitrogen fertilizers on the growth and nitrate content of lettuce (Lactuca sativa L.). International Journal of Environmental Research and Public Health, 11(4), 4427-4440. http://doi.org/10.3390/ijerph110404427

Morais, T. P., Brito, C. H., Ferreira, A. S., \& Luz, J. M. Q. (2015). Morphophysiological aspects of maize plants and soil biochemistry due to nitrogen fertilization and maize seed inoculation with Azospirillum brasilense. Revista Ceres, 62(6), 507-509.

Pedó, T., Aumonde, T. Z., Martinazzo, E. G., Villela, F. A., Lopes, N. F., \& Mauch, C. R. (2014). Growth analysis of radish plants subjected to doses of nitrogen. Bioscience Journal, 30(1), 1-7.

Porto, M. L. A., Puiatti, M., Fontes, P. C. R., Cecon, P. R., Alves, J. C., \& Arruda, J. A. (2012). Zucchini yield and nitrate accumulation in fruits as a function of the nitrogen fertilization. Bragantia, 71(2), 190-195. https://doi.org/10.1590/S0006-87052012005000020

R Core Team. (2018). R: A language and environment for statistical computing. R Foundation for Statistical Computing. Vienna, Austria.

Ramos, A. R. P., Santos, R. L., Amaro, A. C. E., Fumes, L. A. A., Boaro, C. S. F., \& Cardoso, A. I. (2013). Efficiency of potassium silicate in powdery mildew control and development of summer squash. Horticultura Brasileira, 31(3), 432-438. https://doi.org/10.1590/S0102-05362013000300014 
Ribeiro, R. V., Silva, L., Ramos, R. A., Andrade, C. A., Zambrosi, F. C. B., \& Pereira, S. P. (2011). High soil silicon concentrations inhibit coffee root growth without affecting leaf gas exchange. Revista Brasileira de Ciência do Solo, 35(3), 939-948. https://doi.org/10.1590/S0100-06832011000300028

Taiz, L., Zeiger, E., Moller, I. M., \& Murphy, A. (2017). Fisiologia vegetal (6th ed., p. 818). Porto Alegre: Artmed.

Xu, G., Fan, X., \& Miller, A. J. (2012). Plant nitrogen assimilation and use efficiency. Annual Review of Plant Biology, 63, 153-182. https://doi.org/10.1146/annurev-arplant-042811-105532

Zamboni, M., Garavani, A., Gatti, M., Vercesi, A., Parisi, M. G., Bavaresco, L., \& Poni, S. (2016). Vegetative, physiological and nutritional behavior of new grapevine rootstocks in response to different nitrogen supply. Scientia Horticulturae, 202, 99-106. https://doi.org/10.1016/j.scienta.2016.02.032

\section{Copyrights}

Copyright for this article is retained by the author(s), with first publication rights granted to the journal.

This is an open-access article distributed under the terms and conditions of the Creative Commons Attribution license (http://creativecommons.org/licenses/by/4.0/). 